
www.globaliournalseries.com; Info@globaljournalseries.com

\title{
TEACHERS COMPETENCIES IN EVALUATION OF COMPETENCY BASED CURRICULUM AMONG SPECIAL NEEDS LEARNERS IN KENYA
}

NELLY C. ANDIEMA

(Received 24, August 2020; Revision Accepted 9, September 2020)

\begin{abstract}
Assessment and evaluation activities are conducted to determine whether the curriculum content provided to students resulted to gain of knowledge and understanding. With the Kenya implementing the new Competency Based Curriculum (CBC), not much has been focused on the level of teacher understanding and preparedness towards evaluating special needs learners enrolled in public primary schools. This paper looks at teacher competencies for evaluation of CBC among special needs learners in public primary schools in Kapsaret Sub County, Kenya. The target population involved 83 public primary schools located in the sub county with special needs teachers of the targeted primary schools forming the target population. A sample size of 69 special needs teachers was selected as the sample for the study selected through simple random sampling method. To collect data, questionnaire was used. The analysis of data was done using quantitative and qualitative methods. Research result showed that majority of special needs teachers were not adequately prepared to undertake evaluation and assessment of children with special needs in line with the new curriculum. The lack of adequate understanding and application of formative assessment methods by special needs teachers denied the special needs learners opportunity to acquired competencies and skills as per CBC curriculum. The paper therefore recommends that special needs teachers like other teachers need to be regularly provided with adequate training on different methods of assessment of special needs learners in their classroom. This will ensure that the goals of inclusion are attained hence contributing to special needs learners education growth and development.
\end{abstract}

KEYWORDS: Special, Needs, Evaluation, Assessment, Teachers, Children

\section{INTRODUCTION}

The adoption of competency based curriculum in Kenya was aimed at improving the quality of teaching and learning in the country (Andiema, 2020). This new curriculum (2-6-3-3-3) replaced the unpopular (8-4-4) that was blamed for producing graduates who were not competent enough to meet the job market skills. Scheopner,
Brett, Cox and Greller (2018) explain that the competency based curriculum requires learners to demonstrate mastery of content which happens through assessments where they apply knowledge taught. To special needs learners, they need personalised instruction to ensure they master the content being taught in classrooms. This means that there has to be change in traditional evaluation and assessment practices

Nelly C. Andiema, School of Education Kibabii University P.O. Box 1699 - 50200, Bungoma, Kenya 
that used to dominate education sector in the country. The implementation of $\mathrm{CBC}$ requires the use of new assessment methods aligned with the new curriculum (Makunja, 2015). To implement changes brought about by the new assessment methods it is necessary that all special teachers become knowledgeable and better equipped with new alternative approaches to assessment of special needs learners in schools. Tanzania is one of the countries that preceded Kenya in the adoption and implementation of CBC but a research conducted by Paulo (2014) noted that despite the fact that teacher trainees (in colleges) knew about the assessment methods to be used for competency based curriculum, they were not using the recommended methods in their teaching practice sessions in schools. They tended to use the traditional assessment methods which resulted to learners not attaining the required competencies. This was also confirmed by Lukindo (2016) research done in the same country where no changes had been made in terms of assessments of students in schools hence defeating the goal of introducing the curriculum in schools.

The gap in providing the required assessment to special needs learners in schools may not be a problem by the teachers but other supportive bodies linked to them. For instance, a research by Jelagat (2020) in several North Rift and Western Kenya counties of Kakamega, Baringo, Trans Nzoia, Uasin Gishu, and Elgeyo Marakwet found out that Educational Assessment Resource Centers (EARCs) in those counties rarely instituted educational programs specifically designed to cater for the special needs children. This means that the government could have failed to adequately prepare special needs teachers with adequate training on methods of assessment before rolling out the new curriculum that had reached grade four in the year 2020 . The lack of assessment programmes for special needs learners in the wake of implementation of competency based curriculum is a setback towards realising the objectives of competency based curriculum in the country. Ideally, the EARCs are supposed to assist special needs teachers in the country to assess learners and know the kind of support they need to ensure that their learning runs smoothly.

\section{STATEMENT OF THE PROBLEM}

The government of Kenya has ratified all international conventions on providing education for all irrespective of their abilities. With new educational change requiring that children with special needs to attend normal classrooms through inclusion policy, the number of these learners have increased in public primary schools. This has been necessitated by the government ensuring that each public primary school within the country has a special needs teacher trained to work together with other teachers to ensure full implementation of inclusive education without discrimination to special needs learners. With the new CBC curriculum in place (from pre-school to grade four as of 2020), it is expected that the special needs teachers have the necessary assessment and evaluation capacities to check on the extent to which special needs learners have mastered the curriculum content. Research conducted in Tanzania has shown teachers using the traditional practices which are not prescribed in $\mathrm{CBC}$ and were prevalent in the country. This paper therefore seeks to establish the teachers' competencies in evaluation of CBC among special needs learners in Kapsaret Sub County, Kenya.

\section{LITERATURE REVIEW}

UNESCO defines CBC as a curriculum which emphasises the complex outcomes of a learning process (knowledge, skills and attitudes to be applied by learners) rather than mainly focusing on what learners are expected to learn about in terms of traditionally-defined subject content. This means that the learning is learner centered and adaptable to changing needs of society, students and also teachers. Bandura (1990) indicates that competence not only involves knowledge and skills, but also the capacity to use these effectively in various situations and under diverse reasons. In competency based classrooms, learners acquire and apply knowledge skills and attitudes to scenarios that the encounter in their everyday life (Ineke et al., 2018). Through this, majority of countries across the world have reformed their education systems to competency based. O'Sullivan and Burce (2014) reported that there is a growing trend 
towards competency-based education in Europe. In Kenya, competency based curriculum was introduced at a time that Kenya is vigorously pursuing vision 2030 and this has seen its implementation reaching grade four in the year 2020 (Momanyi \& Rop, 2019). The CBC seeks to ensure that all learners benefit from education irrespective of their abilities. This has happened through inclusive education practices.

Inclusive education the full integration of learners with and without special needs into the same classrooms and schools and hence exposing them to the same learning opportunities (Eskay \& Oboegbulem, 2013). Adoyo (2017) indicated that inclusive education involves transformation of regular schools into barrier free environment to accommodate all learners irrespective of their abilities. Galevska and Pesic (2018) explains that inclusive education meant that the child with special educational needs goes to school with his friends; programmes and methods of teaching are adapted according to its possibilities; the teacher is further prepared to work with the child by undergoing training to ensure they integrate special needs learners in their classroom. Eskay and Oboegbulem (2013) observed that education in an inclusive setting appears to be a concept in this 21st century through ratifying United Nations (UN) 2006 Convention on the Rights of People with Disability. This has seen the policy being ratified by majority of countries across the world. Walsh (2018) reported that inclusion of learners with special needs in normal classrooms classroom is a legal requirement in the United States of America according based on Individuals with Disabilities Education Act [IDEA]. In Kenya, the Basic Education Act (2013) champions for progressive inclusion, non-discrimination, encouragement and protection of the persons with disabilities in the education sector right from pre-primary to universities.

Despite the initiatives taken by governments across the world to promote inclusive education, reports show that the policies have no yet succeeded across the globe. In Belgium, Lebeer, Partanen, Candeias, et al. (2015) noted that although governments have recognised the need to make basic education more accessible to children with special needs, many children remain excluded from participation in regular school settings. Tsisindu, Joel and Edward (2016) noted that the countries education system have been characterised by inadequate educational management practices that do not respond well to the challenges faced by special needs learners. Mbugua, Cheboi, Omuga and Madigu (2016) noted that the move towards inclusive education remains elusive. There is dramatic difference in the educational opportunities provided for children with Intellectual Disability (ID) and without ID. Various factors have been mentioned to affect the realisation of the goals of inclusive education which is evaluation and assessment methods used.

In Macedonia, Galevska and Pesic (2018) observed that assessing the educational development of learners with special needs is very challenging for the teachers and they often express the need for accurate and precise guidance in applying the assessment practices in the inclusive classrooms. In Nigeria, Eskay and Oboegbulem (2013) noted that assessment is an important ingredient in the whole process of inclusive education. Observation, screening, referral, evaluation, identification, and individualized education plans relate to the assessment process. KICD (2017) noted that assessment is an important component in the teaching and learning process, since it is the basis of evaluating of the effectiveness of the implementation CBC curriculum process. Teachers and learners use various modes of assessment to determine performance as well as identify gaps. Unfortunately, Eskay (2009) discovered that teachers have difficulty in assessing and appropriately placing learners with special in inclusive setting. This challenge has been blamed to their lack of exposure to the knowledge of special education. In Botswana, Mangope, Kuyini and Major (2012) indicated that children are generally admitted into grade one without any form of assessment to ascertain if they have any special needs. This has led to a number of children with special needs entering the education system un-assessed and without classroom and learning provisions for them. Hyunjeong et al. (2014) observed that many teachers were not taught how to teach students with special needs, yet alone include students 
with special needs in their general education classroom in South Korea and United States of America. This means that teachers need to be aware on the evaluation methods to use when assessing learners with special needs inclusive classroom an area that this study investigates.

\section{EMPIRICAL STUDIES}

In United States of America, Scheopner, Brett, Cox and Greller (2018) qualitative case study describes how three districts in New Hampshire implemented competency education reform in secondary schools. Findings reveal that despite over 6 years of progress at each site, the reform had not been fully implemented due to inertial, technical, normative, and political challenges. Changes to grading and assessment were particularly difficult to implement.In Macedonia, Galevska and Pesic (2018) observed that teachers in the educational process had difficulty in their efforts to assess the knowledge accurately and adequately when it came to learners with special educational needs, especially those involved in the inclusive classrooms. In the absence of specialised policies and recommendations, many teachers applied informal, individual assessment and adaptations to learners with disabilities. In Philippines, Villamero (2014) explored how the three regular primary school teachers in Negros Oriental, Philippines assess children with disabilities in the regular classrooms. The researcher utilised a constructivist methodology, which allowed this qualitative study to understand the experiences of the teachers. These experiences were explored by utilizing two constructivist tools, semi-structured interviews and direct classroom observations. The assessment strategies that teachers employed are based on the diagnostic, formative, and summative purposes of assessment. Under these three purposes, teachers employed assessment strategies such as tests, observations, portfolios, and groupings. Finding indicates that in assessing children with special needs, teachers needed employ a variety of assessment strategies. In delivering the mentioned assessment strategies to children with disabilities, the teachers modify the content and delivery based on the needs of the children.
In Botswana, Mangope, Kuyini and Major (2012) examined the role and functions of the Botswana Assessment Centre in diagnosing the learning needs of primary school students. Forty-nine teachers from primary schools in Gaborone and surroundings responded to a thirteen-item questionnaire. Data from this questionnaire was analysed using descriptive statistics, t-tests and ANOVA. The results also revealed that although the majority of schools had School Intervention Teams (SIT) who were responsible for referring students to assessment, the role of teams was unclear in some schools. In Tanzania, Mapunda, Omollo and Bali (2017) assessed if there was a functioning school based system of assessment for identification and intervention programmes for children with special needs in pre-primary schools around Dodoma municipality. They employed qualitative research approach with some elements of quantitative research. Data was collected through interviews and documentary review. Findings of the study revealed that there were no special educational needs policy implementation frameworks necessary to enforce the provision of special educational needs for pre-primary children in Dodoma municipality. This created a gap between the intended policy outcome and what was actually implemented at the municipal and school level. Feruzi and Yang (2019) examined implementation of competence based curriculum in Tanzania using the FIRST framework. The method adopted was reviewing secondary works. It was found that teachers gave students very low performance task during learning process. Though both formative and summative assessments are important but formative assessment enhances strong foundation for students' academic progress. In this case it was expected that teachers give students enough activities, quizzes and assignments to strengthen their understanding. In Tanzania Paulo (2014) investigated pre-service teachers' preparedness to implement competence based curriculum for secondary schools. It involved 16 purposively selected pre-service teachers trained at the University of Dar es Salaam. Findings showed that although pre-service were aware of the teaching and assessment methods stipulated to 
be used for the implementation of competence based curriculum they were not adopting the envisaged methods in their classroom practices. Majoko (2019) examined the teaching competencies perceived by special needs education teachers to be essential for inclusive education. Entrenched in inclusive pedagogy, this descriptive study draws on a sample of 24 special needs education primary school teachers purposively drawn from Midland educational province of Zimbabwe. Throughout the analysis of data, a constant comparative approach of the organization of data with continual adjustment was used. The study found that participants perceived screening and assessment, differentiation of instruction, classroom and behaviour management, and collaboration to be key competencies required of teachers for inclusive education.

In Kenya, Tsisindu, Joel and Edward (2016) determine the extent to which the teaching and learning strategies were employed to meet the academic needs of learners with special needs in primary schools. The target population was 90 head teachers, 999 teachers and one Educational Assessment and Resource Centre (EARC) coordinator. The schools were stratified according to zones and simple random sampling was used to select, 18 head teachers and 200 teachers, while the EARC coordinator was selected by the purposive sampling technique. The research findings revealed that teachers lack relevant skills to meet the academic needs of LWSNs and they rarely address learners' needs through the individualised education programmes (IEP). Adoyo (2017) sought to establish the extent to which teachers had implemented inclusive education practices. Descriptive Survey research design was used in the study. Target population comprised 216 teachers and 72 head teachers. Study sample comprised of 196 teachers and 65 head teachers selected through saturated sampling approach. Results indicated that schools lacked policy documents on inclusive education in their custody, there was fair assessment on admission, the number of trained teachers was significantly low, the curriculum was not being differentiated in most schools, and there was lack of provision of related services. All these had implications on implementation of inclusive education. KICD (2017) research sought to establish formative and summative assessment modes for competency based curriculum for SNE institutions. This study applied a mixed methods design which involved both quantitative and qualitative approaches, conceptualised as a survey therefore both questionnaires, observation schedules, interviews, focused group discussions (FGDs) and submitted memoranda were used as data sources. The respondents advocated for comprehensive functional assessment in both health and educational assessments at an early stage so as to ascertain type and severity of disability for proper placement and intervention. To this end, Educational Assessment and Resource Centres (EARCs) are crucial if education for all is to be achieved. The findings of the needs assessment indicated preference for formative assessment, continuous assessment, oral assessment, project and use of observation as appropriate assessment methods for learners with special needs. The need for flexibility of assessment through adaption of time, test items, mode of response, print size, colour and size of the paper to suit specific learners with special needs was underscored. The findings also revealed the need to develop special examinations for learners with special needs. There is also need to carry out an early functional assessment for early intervention. Jelagat (2020) study was to analyze the problems affecting Educational Assessment Resource Centers in Kakamega, Baringo, Trans Nzoia, Uasin Gishu, and Elgeyo Marakwet counties. The study used a descriptive survey approach. The study involved 15 County Education Officers and 80 Special Needs Teachers selected through purposive sampling. The study also found out that EARCs rarely instituted educational programs specifically designed to cater to special needs children. Additionally, the study deduced that $9(60 \%)$ County Education Officers did not fully understand the role of the EARCs in their counties.

\section{MATERIALS AND METHODS}

The study methodology involves qualitative and quantitative approaches to data collection. A descriptive survey research design was used. The study area was Kapsaret Sub County, Uasin Gishu County, Kenya. All public primary schools in the sub county formed the target population with special needs education teachers teaching in mainstream sections of the schools. The competency based curriculum is implemented across all primary schools (private or public) in the country. Therefore, the decision to choose Kapsaret Sub County is to act as representatives of the situation among SNE teachers in other areas of Kenya. A total of 83 SNE teachers formed the target population. Using a sample 
size formular, when the population is 83 , confidence level at $95.0 \%$ and margin of error at $5 \%$, the sample size is 69 . Therefore, 69 SNE teachers from public primary schools in Kapsaret Sub County formed the sample. The selection of the sample was done randomly from the 83 using randomisation method. Collection of data was facilitated through use of questionnaire which was designed according to the study objectives. The questionnaires were distributed by the researcher to the sampled teachers within a span of two weeks after getting necessary approvals from Sub County Director of Education. Data analysis was performed using qualitative and quantitative methods. Quantitative data was coded and entered in electronic spreadsheets with the help of SPSS. Analysis of quantitative data was done using descriptive statistics. Open ended responses are provided in narrations in the next section.

\section{RESULTS AND DISCUSSIONS}

The research involved participation of special needs teachers from selected public primary schools in Kapsaret Sub County, Kenya. Review of demographic data showed that 57 (82.6\%) were female whereas $12(17.4 \%)$ were males. This shows that special needs education profession appear to attract female teachers compared to male in the country. With regard to their education qualification level, $3(4.3 \%)$ had certificate in special needs education, 42 (60.9\%) possessed diploma in special needs education and $24(34.8 \%)$ had Bachelor of Arts degree in special needs education. These result shows that the SNE teachers teaching in public primary schools have the required qualifications to enable them teach and support special needs learners in their schools. The experience that the teachers had in teaching special needs education in primary schools ranged from 2 years to a maximum of 15 years. The average number of teaching experience was 7 years and this means that most teachers were in a position to know the previous assessment used in the 8-4-4 system of education and the new one required under the 26-3-3-3 system which is competency based. Analysis of enrolment data from public primary schools in the Sub County showed that there has been significant increase in admission for learners with special needs in public primary schools in Kapsaret Sub County. The main categories of learners with disabilities enrolled in the public primary schools were those with learning disabilities, communication impairments, physically handicapped, gifted and talented.

To answer the objective of the paper, KICD curriculum document specifies the kind of assessment that special needs teachers' needs to utilise in their classroom instruction to establish the extent to which the content being taught is mastered by the learner. Therefore, the special needs teachers were asked to indicate the degree at which they applied the assessment and evaluation methods for their special needs children in their class. The results of analysis are presented in Table 1. 
Table 1: Extent of Teacher Assessment and Evaluation of Special Needs Children in Primary Schools

\begin{tabular}{|l|l|l|l|l|l|l|l|}
\hline Assessment \& Evaluation & SDA & $\mathbf{D}$ & $\mathbf{N}$ & $\mathbf{A}$ & SA & M & SD \\
\hline $\begin{array}{l}\text { I provide multiple test format for } \\
\text { special needs pupils in my } \\
\text { classroom }\end{array}$ & $\begin{array}{l}5 \\
(7.2 \%)\end{array}$ & $\begin{array}{l}9 \\
(13.0 \%)\end{array}$ & $\begin{array}{l}11 \\
(15.9 \%)\end{array}$ & $\begin{array}{l}17 \\
(24.6 \%)\end{array}$ & $\begin{array}{l}27 \\
(39.1 \%)\end{array}$ & 3.75 & 1.30 \\
\hline $\begin{array}{l}\text { I collect data through notes \& } \\
\text { checklists to keep track of } \\
\text { learners strengths and needs }\end{array}$ & $(15.9 \%)$ & $\begin{array}{l}11 \\
(15.9 \%)\end{array}$ & $\begin{array}{l}23 \\
(33.3 \%)\end{array}$ & $\begin{array}{l}21 \\
(30.4 \%)\end{array}$ & $3(4.3 \%)$ & 2.91 & 1.13 \\
\hline $\begin{array}{l}\text { I use evaluation data to assess } \\
\text { the attainment of goals set in } \\
\text { IEP and to set new goals }\end{array}$ & $(27.5 \%)$ & $(11.6 \%)$ & $\begin{array}{l}17 \\
(24.6 \%)\end{array}$ & $\begin{array}{l}20 \\
(29.0 \%)\end{array}$ & $5(7.2 \%)$ & 2.76 & 1.33 \\
\hline $\begin{array}{l}\text { I liaise with EARCs to conduct } \\
\text { assessment of pupils unique } \\
\text { needs }\end{array}$ & $(7.2 \%)$ & $\begin{array}{l}8 \\
(11.6 \%)\end{array}$ & $\begin{array}{l}26 \\
(37.7 \%)\end{array}$ & $\begin{array}{l}23 \\
(33.3 \%)\end{array}$ & $(10.1 \%)$ & 3.28 & 1.04 \\
\hline $\begin{array}{l}\text { Using pre-assessment } \\
\text { formative activities before } \\
\text { beginning a unit }\end{array}$ & $7(10.1 \%)$ & $\begin{array}{l}11 \\
(15.9 \%)\end{array}$ & $\begin{array}{l}32 \\
(46.4 \%)\end{array}$ & $\begin{array}{l}13 \\
(18.8 \%)\end{array}$ & $6(8.7 \%)$ & 3.00 & 1.06 \\
\hline $\begin{array}{l}\text { Using pre-assessment } \\
\text { formative activities to discover } \\
\text { learners who might need } \\
\text { instruction outside regular } \\
\text { classroom }\end{array}$ & $(7.2 \%)$ & $\begin{array}{l}13 \\
(18.8 \%)\end{array}$ & $\begin{array}{l}18 \\
(26.1 \%)\end{array}$ & $\begin{array}{l}22 \\
(31.9 \%)\end{array}$ & $\begin{array}{l}11 \\
(15.9 \%)\end{array}$ & 3.30 & 1.17 \\
\hline $\begin{array}{l}\text { I provide all learners with } \\
\text { formative feedback to indentify } \\
\text { performance gaps }\end{array}$ & $\begin{array}{l}4 \\
(5.8 \%)\end{array}$ & $\begin{array}{l}12 \\
(17.4 \%)\end{array}$ & $\begin{array}{l}8 \\
(11.6 \%)\end{array}$ & $\begin{array}{l}30 \\
(43.5 \%)\end{array}$ & $\begin{array}{l}15 \\
(21.7 \%)\end{array}$ & 3.58 & 1.18 \\
\hline $\begin{array}{l}\text { I regular monitor progress of } \\
\text { each learner in my classroom }\end{array}$ & $\begin{array}{l}4 \\
(5.8 \%)\end{array}$ & $\begin{array}{l}12 \\
(17.4 \%)\end{array}$ & $\begin{array}{l}19 \\
(27.5 \%)\end{array}$ & $\begin{array}{l}26 \\
(37.7 \%)\end{array}$ & $\begin{array}{l}8 \\
(11.6 \%)\end{array}$ & 3.32 & 1.08 \\
\hline Composite data & & & & 2.97 & 1.14 \\
\hline
\end{tabular}

Key: SDA-Strongly Disagree, D-Disagree, N-Neutral, A-Agree, SA-Strongly Agree, M-Mean and SDStandard Deviation.

Results show that $27(39.1 \%)$ of special needs teachers strongly agreed and $17(24.6 \%)$ agreed that they provide multiple test format for special needs pupils in classroom. this means that majority of teachers tended regularly $(M=3.75$ and $S D=1.30$ ) use multiple set questions to evaluate and assess special needs learners in their schools. this is because the multiple sets questions have multiple answers to which the learner can be able to choose the right one. Nevertheless, the multiple choice questions are provided at regular intervals so that teacher can understand the level at which learners have mastered specific curriculum content and which they have not. Research findings also showed that $23(33.3 \%)$ of special needs teachers neither agreed nor disagreed (were neutral) on whether they collected data through notes and checklists to keep track of learners strengths and needs. However, 21 (30.4\%) agreed and 3 (4.3\%) strongly agreed with the statement whereas 22 $(31.8 \%)$ appeared to disagree with the statement. The research henceforth suggests that teachers sometimes $(M=2.91$ and $S D=1.13)$ collect data through checking learners notes to establish their areas of strengths and needs during assessment process. This means that this practice is not conducted on regular occasions by teachers in 
schools. The lack of regular checking of learners notes to help the special needs teachers identify the areas which the learners need support could affect their educational development as the current curriculum demands that learners master the required competency so as to move to the next grade or unit.

In teaching of special needs learners, individual educational plans are widely proposed in the new CBC curriculum. Therefore, teachers have to utilise IEPs to conduct classrooms instruction. Research result showed that $19(27.5 \%)$ of teachers agreed not to be using evaluation data obtained from IEP records to set new curriculum goals for the learner, $8(11.6 \%)$ disagreed, 17 $(24.6 \%)$ were neutral, $20(29.0 \%)$ agreed and 5 $(7.2 \%)$ strongly agreed. The research suggest that the usage of evaluation data to assess the attainment of goals set in EIP is moderately done $(M=2.76$ and $S D=1.33)$ by special needs teachers in Kapsaret Sub County, Kenya. This means that the lack of regular usage of evaluation data obtained from IEP could be due to the reluctance by special needs teachers to use them, poor record keeping or even lack of IEP usage by teachers during curriculum instruction for special needs learners.

In Kenya, every county and some specific sub counties are provided with EARCs to help special needs teachers in identifying, supporting, training and assessment of special needs children. The EARCs provide additional support and teachers have to constantly liaise with them. The research findings showed that $26(37.7 \%)$ said that they sometimes liaised with EARCs officer, 23 (33.3\%) admitted that they often used them and $13(18.8 \%)$ have never liaised with the EARCs officers to conduct assessment of special needs pupils needs. The lack of assessment by EARCs may result to lack of provision of required curriculum support to special needs learners as they may be wrongly identified or diagnosed the challenge that they are facing. The assessment of EARCs also helps teachers to plan the learners' instructional methods to be used when they are integrated in inclusive classroom settings.
The adoption of CBC in Kenya was aimed at abolishing summative assessment criteria that was used to determine whether a learner proceeded to the next class or next level of education. The CBC emphasises continuous assessment (formative) to ensure that special needs academic progress is monitored and where help is needed, it is provided by the teacher. Research outcomes showed that close to half $32(46.4 \%)$ of teachers said that they sometimes used pre-assessment formative activities before beginning a new unit, $13(18.8 \%)$ agreed with the statement and 11 (15.9\%) disagreed. The result means that preassessment of formative activities is moderately $(M=3.0$ and $S D=1.06)$ performed. This means that at times, special needs teachers begin a new unit without conducting pre-assessment activities of the previous unit that they had taught to know whether the special needs learners understood the subject matter. The lack of conducting preassessment formative activities may affect special needs learners' acquisition of required competencies, knowledge and skills in the new curriculum hence putting them behind their able bodied colleagues in schools.

Probed further on whether the pre-assessment formative activities are used to discover the special needs learners who might need instruction outside inclusive classroom, 5 (7.2\%) strongly disagreed, $13(18.8 \%)$ disagreed, 18 $(26.1 \%)$ were neutral, $22(31.9 \%)$ agreed and 11 $(15.9 \%)$ strongly agreed. The result shows that at least $47.8 \%$ of special needs teachers utilise result of pre-assessment activities to identify whether the learners will continue learning under inclusive setting or any other prescribed mode of learning. This means that pre-assessment activities report are sometimes $(\mathrm{M}=3.30$ and $S D=1.17$ ) used to discover whether some special needs learners may need additional instructional support that may not be found in their inclusive classroom setting. This happens in situations where assistive devices or external support (EARCs) may be needed and when the teacher identifies this need early, it will help to make plans for proper provision of the needed 
instructional services. Through pre-assessment formative activities, the special needs teachers may also collaborate with parents of the special needs children to plan the best instructional support that their child may require to further his/her education.

In CBC curriculum, it is expected that feedback is provided to the learner regularly to enable them proceed well with their education. When asked as to whether they provided all learners with formative feedback as a way of identifying performance gaps, $4(5.8 \%)$ strongly disagreed, $12(17.4 \%)$ disagreed, $8(43.5 \%)$ were neutral, 30 $(43.5 \%)$ agreed and $15(21.7 \%)$ strongly agreed. The result means that $65.2 \%$ of special needs teachers provide their special needs learners with formative feedback report so that performance or competency gaps can be corrected. This means that special needs learners are provided with the feedback from assessment to enable them identify areas to which they need to correct and move forward with their education. Research result also showed that $26(37.7 \%)$ of special needs teachers admitted that they regularly monitored the progress of every learner (including those with special needs) in their classrooms. However, $19(27.5 \%)$ neither agreed nor disagreed, $12(17.4 \%)$ disagreed and 4 $(5.8 \%)$ strongly disagreed. Nevertheless, close to half $(49.3 \%)$ of special needs teachers monitor the academic progress of their learners in classroom but the other half did not. This is exacerbated by high pupil: teacher ratio in classroom beyond 35 pupils per class required by the Ministry of Education. When the learner population exceeds 35 pupils, it becomes impossible for the teacher to monitor each learner and those who are found at risk are special needs learners who may need additional instructional support in contrast to their able bodied colleagues. Composite data from the above statements reveal that the level of special needs teacher assessment and evaluation of competency based curriculum among special needs learners enrolled in inclusive classrooms in Kapsaret Sub County, Kenya is at average level $(M=3.24$ and $S D=1.16)$.

This is diagrammatically presented in Figure 1.

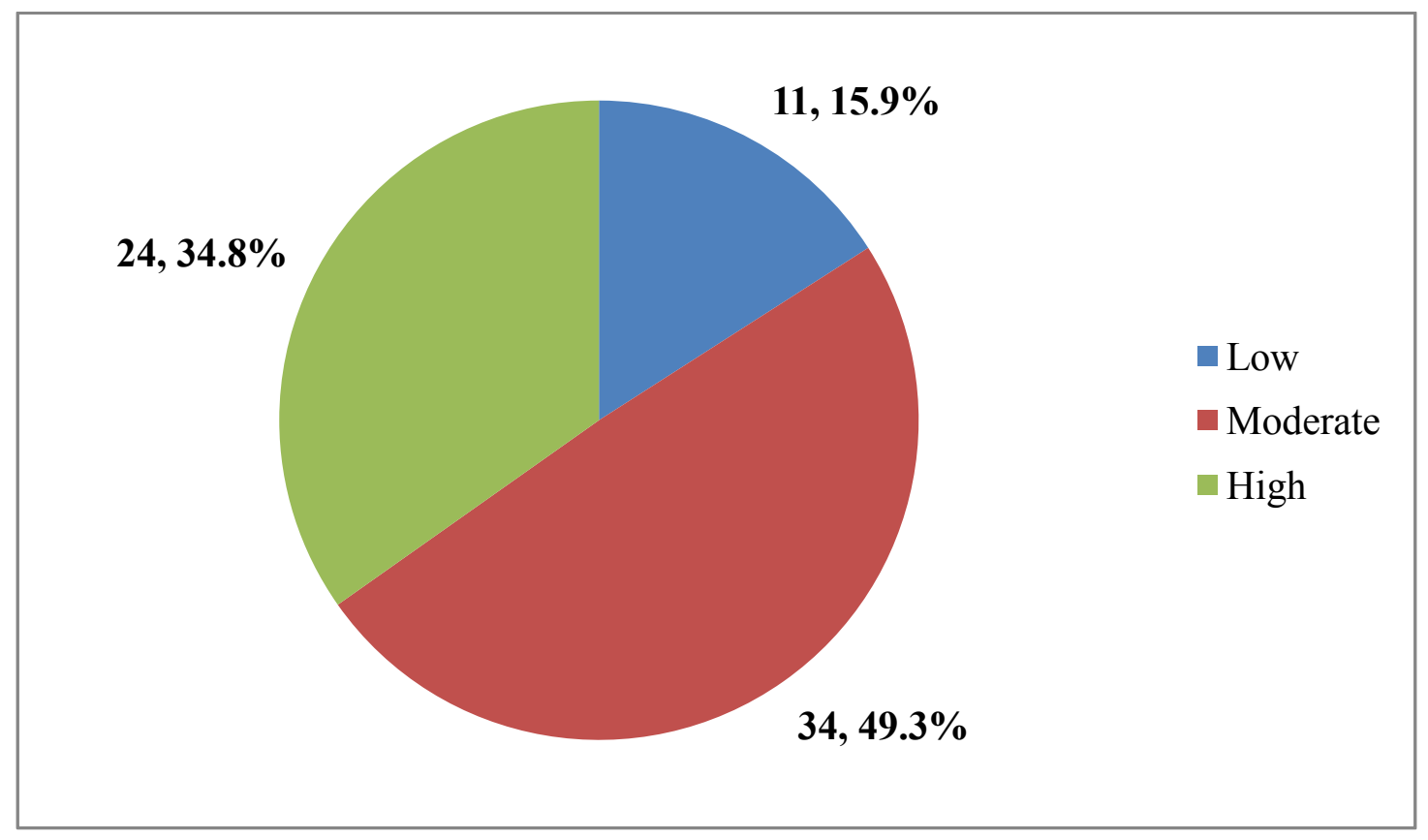

Figure 1: Summary Teacher Competencies Evaluation of Special Needs Learners

The result show that $34(49.3 \%)$ of special needs teachers capacity to conduct evaluation and assessment for special needs learners through the new $\mathrm{CBC}$ curriculum was at an average level. It can also be seen that $11(15.9 \%)$ of teachers had low assessment and evaluation competency level and 24 (34.8\%) were found to have higher level of competencies in evaluating and assessing special needs learners in inclusive classrooms in Kapsaret Sub County, Kenya. 
CONCLUSIONS AND RECOMMENDATIONS

Learners with special needs are not supposed to be placed in different institutions from their able bodied counterparts. They have to enjoy the resources and facilities the mainstreams schools provide to ensure that they acquire necessary skills and competencies. This research has found out that there has been significant admission of children with special needs in public primary schools in Kapsaret Sub County, Uasin Gishu County, Kenya in the past five years. However, analysis of special needs teachers distribution in schools shows that most of the 83 schools have one teacher with less than ten having two or more SNE teachers. The admission of special needs children in mainstream classrooms has presented good opportunity to these learners to enjoy similar privileges like other children. However, the issue of assessment and evaluation has been a hindrance towards their transition to higher classes forcing many to repeat schools. With the introduction of new CBC curriculum, it was expected that it would improve on the disabled learners understanding of the content being taught rather than just passing examinations. The paper has found out that teacher competencies in evaluating and assessment of learners is at an average level in the sub county. The study found out special needs teachers preferred multiple test questions which is associated with summative assessment methods compared to other complementary methods of formative assessment required under CBC. The lack of regular use of formative assessment methods affected the academic progression of special needs learners in inclusive classrooms in Kapsaret Sub County, Kenya. The research recommends that special needs teachers need to be regularly provided with training on the best approaches of assessment and evaluation of CBC curriculum for special needs children. There is also need for the government to train more teachers in primary schools on special needs education so as to increase the enrolment, retention and completion rate of special needs children in public primary schools. Lastly, government should ensure that necessary facilities and assistive educational resources are provided to ensure that the goals of inclusive education under CBC curriculum are obtained.

\section{REFERENCES}

Adoyo, P. O., 2017. Implementation status of inclusive education practices in regular primary schools in Siaya County, Kenya. Maseno: Maseno University.

Andiema, N. C., 2020. Special needs teachers' capacity in the implementation of competency based curriculum in primary schools in Kenya. British Journal of Education, 8(4), 103 - 119.

Bandura, A., 1990. Perceived self-efficacy in the exercise of personal agency. Journal of Applied Sport Psychology, 2(2), 128-163. https://doi.org/10.1080/10413209008406 426.

Eskay, M., and Oboegbulem, A., 2013. Learners with disabilities in an inclusive education setting in Nigeria: Implications for administrators. US-China Education Review B, 3 (5), 313-318.

Eskay, M., 2009. Special education in Nigeria. Koln, Germany: Lambert Academic Publishing.

Feruzi, S. M., and Yang, L., 2019. Teachers' position on implementing competence based curriculum in Tanzania: Adoption of the first framework. International Journal of Research and Innovation in Social Science, 3(9), $411-416$.

Galevska, N. A., and Pesic, M. I., 2018. Assessing children with special needs in the inclusive classrooms. Retrieved on 13-02-2020 from https://www.researchgate.net/publication/ 328891238

Hyunjeong, J., Tyler-Wood, L., Kinnison, L., and Morrison, G. 2014). The US and South Korean pre-k through 6 teachers' beliefs about inclusion practices in their countries: Cross cultural perspectives. The Journal of the International Association of Special Education, 15(2), 11-23. 
Ineke, M. P., Mariya, M., Mireille, K., and Sabine, K-S., 2018. Promoting inclusive education: The role of teachers' competence and attitudes. Insights into Learning Disabilities, 15(1), 49-63.

Jelagat, E. A., 2020. Identification and analysis of the problems facing educational assessment resource centres in five selected counties in Kenya. African Journal Education and Practice, 6 (3), $35-46$.

KICD 2017. Report on needs assessment for reform in kenya special needs

curriculum Nairobi: KICD.

Lebeer, J., Partanen, P., Candeias, A. et al. 2015. The need for a more dynamic and ecological assessment of children experiencing barriers to learning to move towards inclusive education: a summary of results of the Daffodil project. University of Antwerp, Faculty of Medicine and Health Sciences.

Lukindo, J. J., 2016. Exploring competence based education (cbe) in rural secondary schools in Tanzania: English language teachers conceptions and experiences. Journal of Education and Practice, 29(7), $62-67$.

Majoko, T., 2019. Teacher key competencies for inclusive education: tapping pragmatic realities of zimbabwean special needs education teachers. SAGE Open, 1-14.

Makunja, G., 2015. Adopting competence-based curriculum to improve quality of secondary education in Tanzania: "Is it a dream or reality"? International Journal of Education and Research, 3(11), $175-188$.

Mangope, B., Kuyini, A. B., Major, T., 2012. Assessment of learners with special needs for inclusive education in Botswana: Issues and challenges for schools. International Journal of Scientific Research in Education, 5(2), 138-150. Retrieved 14-07-2020 from http://www.ijsre.com

Mapunda, P. H., Omollo, A. D., and Bali, T. A. L., 2017. Challenges in identifying and serving students with special needs in Dodoma Tanzania. ICEP. 11:10. DOI 10.1186/s40723017-0036-8.

Mbugua, W. M., Cheboi, K. S., Omuga, O. B., and Madigu, O. N., 2016. Inclusive education for learners with intellectual disability in public primary schools- Kenya. International
Journal of Medical and

Health Research, 2(3), $89-94$.

Momanyi, J. M., and Rop, P. K., 2019. Teacher preparedness for the implementation of competency based curriculum in Kenya: A survey of early grade primary school teachers' in Bomet East Sub-County. African Journal of Educational and Social Science Research, 6(1), $10-15$.

O'Sullivan, N., and Burce, A., 2014. Teaching and learning in competency-based education. Paper Presented at the Fifth International Conference on e-Learning (eLearning-2014), 22-23 September 2014, Belgrade, Serbia.

Paulo, A., 2014. Pre-Service Teacher's preparedness to implement competencebased curriculum in secondary schools in Tanzania. International Journal of Education and Research, 2(7), $219-230$.

Republic of Kenya 2013. The basic education Act No. 14 of 2013. Nairobi: Government Printers.

Scheopner, A. T., Brett, J., Cox, J. and Greller, S., 2018. Competency education implementation: Examining the influence of contextual forces in three New Hampshire secondary schools. AERA Open, 4(2), 1 - 13. DOI: $10.1177 / 2332858418782883$

Tsisindu, O., Joel, O., and Edward, K., 2016. Inclusive teaching-learning strategies to meet academic needs of learners with special needs in Kenya: A case of Kakamega East Sub-County. IRA International Journal of Education and Multidisciplinary Studies (ISSN 2455- 2526), 5(2), 119-128. doi:http://dx.doi.org/10.21013/jems.v5.n2. p7.

United Nations 206. Convention on the rights of persons with disabilities (CRPD). New York: UN.

Villamero, R., 2014. Teachers' assessment strategies for children with disabilities: A constructivist study in regular primary schools in Negros Oriental, Philippines. Master's Dissertation, University of Oslo.

Walsh, M., 2018. "The inclusion of students with special needs in the general education classroom" Bachelor of Arts Thesis, Dominican University of California. https://scholar.dominican.edu/senior- theses/69. 